\title{
Distribution of Flower Pigments in Perianth of Cattleya and Allied Genera I. Species
}

\author{
Shuichiro Matsui and Mitsuo Nakamura \\ Faculty of Agriculture, Gifu University, Gifu 501-11
}

\begin{abstract}
Summary
Distribution patterns of flower pigments and the shape of epidermal cells in perianth tissues in 11 genera of Laeliinae orchids were investigated in relation to flower colors.

1. The 68 species examined were classified into nine groups on the basis of differences in distribution patterns of the carotenoids and anthocyanins contained in epidermal and/or parenchymatous cells in petal tissues. Yellow and orange flowers in such species as Laelia harpophylla and L. cinnabarina contained carotenoids in both epidermal and parenchymatous cells but those of Cattleya dowiana and L. flava contained them only in parenchymatous cells. Red flowers were ascribed to the coexistence of carotenoids and anthocyanins. In Sophronitis coccinea and L. milleri carotenoids were contained in both the epidermal and parenchymatous cells but anthocyanins only in the epidermis, while L.tenebrosa contained anthocyanins only in the parenchymatous cells.

Purple flowers were classified into three groups according to the presence or absence of anthocyanins in the epidermal and parenchymatous cells. The purplish red flowers of most Cattleya species contained anthocyanins in the parenchymatous cells. Some exceptional Cattleyas, C. intermedia var. aquinii and C.leopoldii, contained anthocyanins in the epidermis of splashed or spotted petals. Laelia species blooming in deep purple flowers contained anthocyanins in the epidermis but those of pale flowers did not.

2. A Hunter's diagram of the color chromaticity of petals was divided into three sections according to hue: in the first, the b/a value of yellow to orange petals was more than . 47, due to carotenoid pigmentation only; in the second, the value lay between .47 and -.13 and the flowers were red due to both carotonoid and anthocyanin pigments with one exception ( $S$. coccinea var. rosea); in the third, with values between -.13 and -1.0, purplish-red, so-called 'orchid tone', prevailed.

In petals containing carotenoids, increased chromas corresponded to greater brightness, but increased chromas caused by intensive anthocyanin coloration in petals and lips corresponded to less brightness, as exemplified in the velvety texture of the lips in Cattleyas.

3. The size and shape of the upper epidermal cells in petals and lips varied by species, but within the same genus the variations were serial ; small cells were square and appeared in glossy flowers, while large ones were triangular and caused the velvety appearance. The augmented size and the change from square to triangular shape might manifest the direction of evolution. Plants with large showy flowers in such species as C.labiata, L. purpurata and Brassavola digbyana had the largest and longest epidermal cells in each genus.
\end{abstract}

\section{Introduction}

Numerous interspecific, intergeneric hybrids of Cattleya ans allied genera (Subtribe

Received for publication February 20, 1986.
Laeliinae) have been produced in order to improve flower characteristics, i. e., the size, shape and color of flowers and desired flowering time. Cross combinations have increased so markedly that much effort has been made 
to breed new varieties yielding bright red or yellow flowers with excellent shape $(4,5)$. Basic information about flower color and perianth substance is necessary for effective breeding and for taxonomy. The taxonomic significance of orchid anthyocyanins has already been proved in various genera and species $(2,3,9)$. Carotenoids, chlorophylls

Table 1. Distribution patterns of flower pigments in perianth and their variations in species.

\begin{tabular}{|c|c|c|}
\hline Classification $^{\mathrm{x}}$ & $\mathrm{y}$ & Species \\
\hline 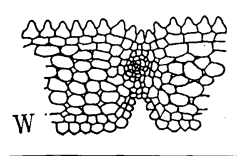 & & 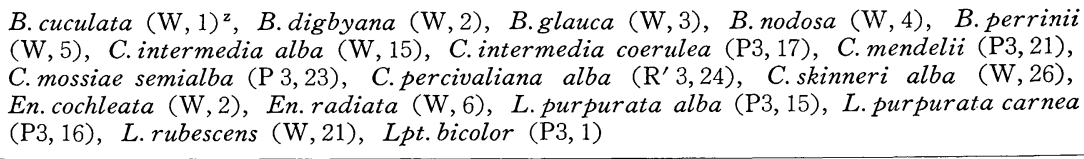 \\
\hline 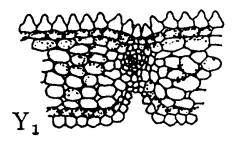 & $\mathrm{Cp}$ & $\begin{array}{l}\text { C. aurantiaca (Y 1,3), C. dowiana (P 3,9), L. flava (Y 1,5), L. mixtra (Y 1, 13). } \\
\text { En. mariae (W, 4) }\end{array}$ \\
\hline ros & $\mathrm{Ce}$ & $\begin{array}{l}\text { C.aurantiaca 'yellew' (Y 2, 4), C. forbesii (Y 2,10), C. granulosa (P 3, 12), C. leopoldii } \\
\text { (P 3, 14), C. velutina (P 3,28), L. cinnabarina (Y 2,3), L.harpophylla (Y 2,6), L. milleri } \\
\text { 'yellow' (Y 2, 12), L.xanthina (W, 20), En. aromatica (1), En.prismatocarpa (5), En. } \\
\text { vitellina (Y 2,7), Epi. cinnabarinum (Y 2,8), Epi. falcatum (Y 2,9) }\end{array}$ \\
\hline $\mathrm{R}_{3}$ & $\begin{array}{l}\mathrm{Cp} \\
\mathrm{Ae} \\
\mathrm{Ap}\end{array}$ & Bro. sanguinea $(\mathrm{R} 3,1)$ \\
\hline 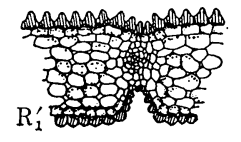 & $\begin{array}{l}\mathrm{Ce} \\
\mathrm{Cp} \\
\mathrm{Ae}\end{array}$ & L. miller $\left(\mathrm{R}^{\prime} 1,11\right)$, S. cernua $\left(\mathrm{R}^{\prime} 1,1\right)$, S. coccinea $\left(\mathrm{R}^{\prime} 1,2\right)$ \\
\hline \multirow{2}{*}{$\mathrm{R}_{2}^{\prime}$} & $\begin{array}{l}\mathrm{Ce} \\
\mathrm{Cp} \\
\mathrm{Ap}\end{array}$ & $\begin{array}{l}\text { C. bicolor (P 2,5), C.dormaniana (P 3, 8), C.granulosa*, En. cordigera (P 2, 3), } \\
\text { L.tenebrosa (P 2, 3), Schom. thomsoniana (Y 2,1) }\end{array}$ \\
\hline & $\begin{array}{l}\mathrm{Ce} \\
\mathrm{Cp} \\
\mathrm{Ae} \\
\mathrm{Ap}\end{array}$ & C. velutina* \\
\hline $\begin{array}{l}150 \\
\mathrm{P}_{1} \\
\end{array}$ & $\mathrm{Ae}$ & $\begin{array}{l}\text { S. coccinea rosea }(\mathrm{P} 1,3) \\
\text { Spn. violacea }(\mathrm{P} 1,1)\end{array}$ \\
\hline $\mathrm{P}_{3}$ & $\mathrm{Ae}$ & 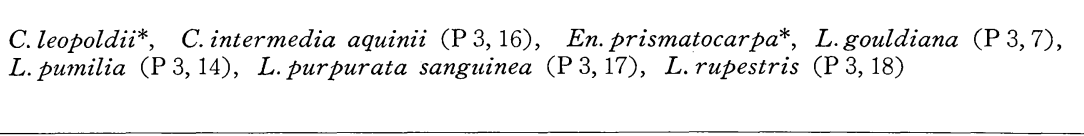 \\
\hline & Ap & 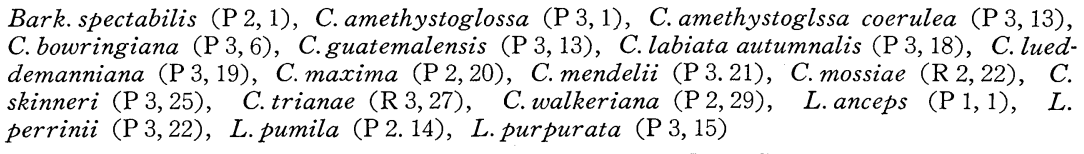 \\
\hline
\end{tabular}

${ }^{z}$ Alphabet letters and arabic numerals in parenthesis indicate the distribution pattern in lips and species number appearing in the following figures.

${ }^{y} \mathrm{Ce}$ and $\mathrm{Cp}$ indicate the presence of carotenoids in epidermal and parenchymatous cells, respectively. Ae and Ap indicate the presence of anthocyanins in epidermal and parenchymatous cells, respectively.

$x$ Dots indicate carotenoids and striped cells contain anthocyanins.

* Distribution in spots and barred patterns in petals. 
and anthocyanins are the main components affecting flower color in orchids. However, variations in flower color are well-known to be affected not only by the chemical nature and amount of pigment but also by the distribution of pigment in tissues and the shapes of the epidermal cells $(11,12)$. The shape and size of epidermal cells also affect flower texture such as a velvety and glossy appearance. Black roses(11) and Renathera orchid flowers(7), which have a velvety appearance, have ovate epidermal cells.

Laeliinae orchids, that is, Cattleya and allied genera, bear flowers with very different colors and substances. However, specific information on species is scanty at preaent. The aims in this study were clarify difference among species and genera in pigment distribution and epidermal cell characteristics, and to examine the relationship between these factors and flower color, from the point of view of their efficacy for taxonomic classification and new crossings.

\section{Materials and Methods}

Flowers of Laeliinae orchids including Barkeria (abbreviation, Bark.), Brassavola(B.), Broughtonia(Bro.), Cattleya(C.), Encyclia (En.), Epidendrum(Epi.), Laelia(L.), Leptotes (Lpt.), Schomburgkia(Schom.), Sophronitella $(S p n$.) and Sophronitis(S.) were collected from the greenhouse of the Experimental Farm of Gifu University, Nagata Engei Co. in Aichi Prefecture, Ohgaki Engei in Gifu Pref., Kokusai Nursery Co. in Tokyo and Ohba Orchids Co. in Tokyo. First, the colors of the dorsal and lateral sepals, petals and lip (labellum) were separately measured with a color chromaticity apparatus (Nihon Denko Model 503-DE). Flower color was expressed in Hunter's color notation. For microscopic observation the petals and lips were hand-sectioned one third of the way from the tips, in the same area as used for the chromaticity measurement. With a micrometer-equipped microscope(Olympus BHS) the size of the epidermal cells of the petals and lips were measured and their shape and the distribution of antocyanins and carotenoids in the tissues observed. Anthocyanins were identifiable by the red to purple color in cell sap and carotenoids by yellow- to orange-colored plastids in the cells $(7,12)$.

\section{Results}

1. Distribution of flower pigments in perianth tissues

Distribution patterns of flower pigments in the petals of the 68 species examined were classified into nine groups on the basis of the presence or absence of carotenoids and anthocyanins in upper epidermal and/or parenchymatous (palisade and spongy) cells (Table 1). Yellow petals contained carotenoids either only in parenchymatous cells (Y 1) or in both parenchymatous and epidermal cells (Y 2). In the parenchymatous tissues palisade cells contained granulated yellow or orange plastids, while in the epidermal cells most colored plastids were deposited at the cell bottom (Fig. $1 \mathrm{a}$ and b). Group Y 1 included C.dowiana, C. aurantiaca and L. Alava and also the leaves belonging to this group, whereas Y 2 included L.harpophylla, L.cinnabarina, L. xanthina and En.vitellina. Carotenoids were contained in yellow lips in the same way as in yellow petals.

Red color was ascribed to the coexistence of carotenoids and anthocyanins. In petals of L. milleri, S. coccinea and Bro. sanguinea anthocyanins were distributed in the epidermal cells, while carotenoids were found in the epidermal cells and parenchymatous tissues in the former two species ( $R^{\prime} 1$, Fig. $1 \mathrm{c})$ and in the parenchymatous ones in the latter (R 3). However, the brown petals of L. tenebrosa, C. bicolor and En. cordigera contained anthocyanins in the parenchymatous rather than the epidermal cells, along with carotenoids and chlorophylls ( $\left.\mathrm{R}^{\prime} 2\right)$. Purplish-red flowers were classified into group P 1, P 2 and P 3, according to whether anthocyanins were found in the epidermis only (P 1), in the parenchymatous tissues (P 2), or in both tissues (P 3). No Cattleya examined contained anthocyanins in the epidermal cells (P 2) (Fig.1f) except for the spots on petals of C.leopoldii and the splashed petals of C.intermedia var. aquinii (Fig. 1d), which were P3. The anthocyanin- 

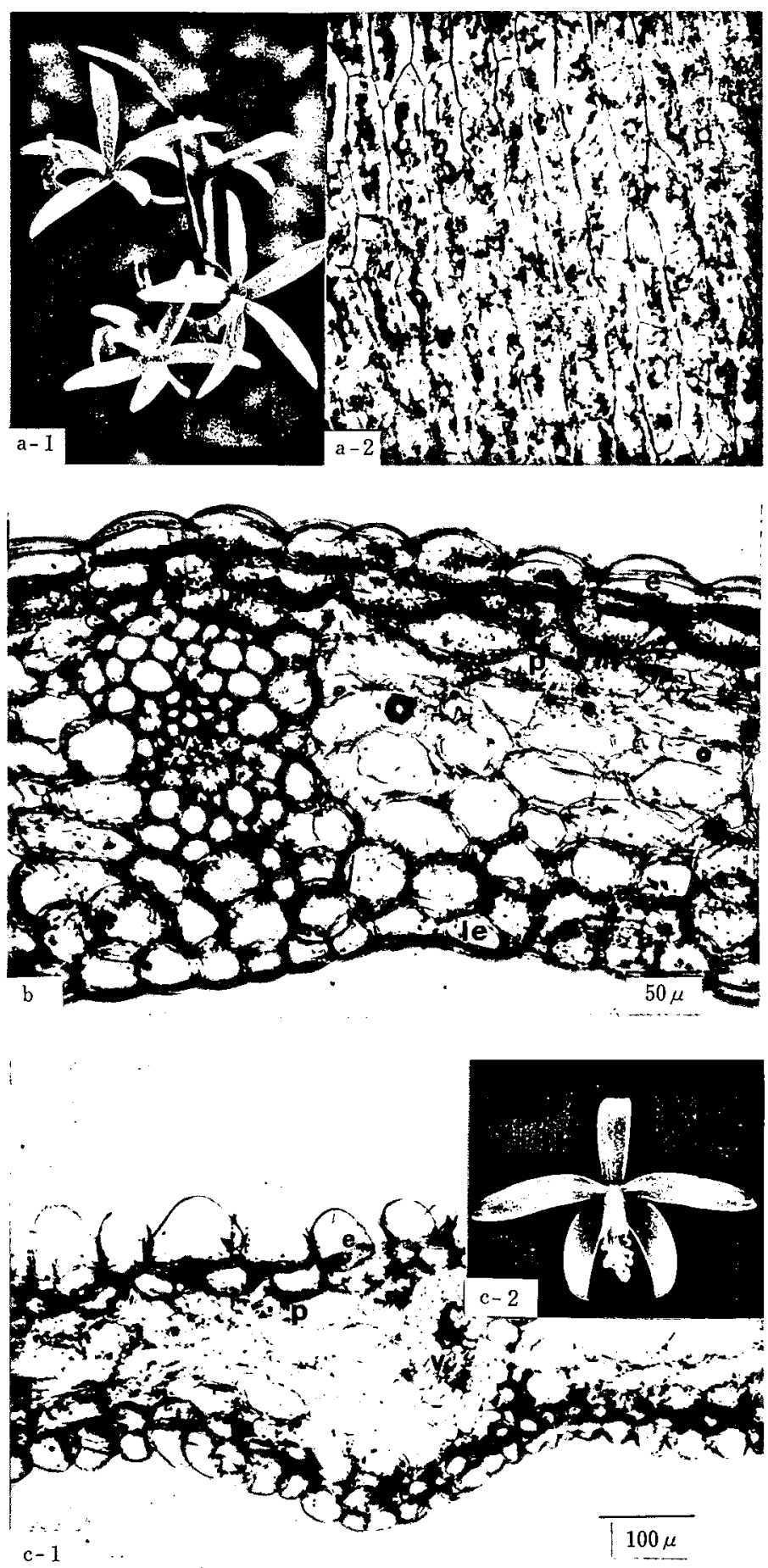

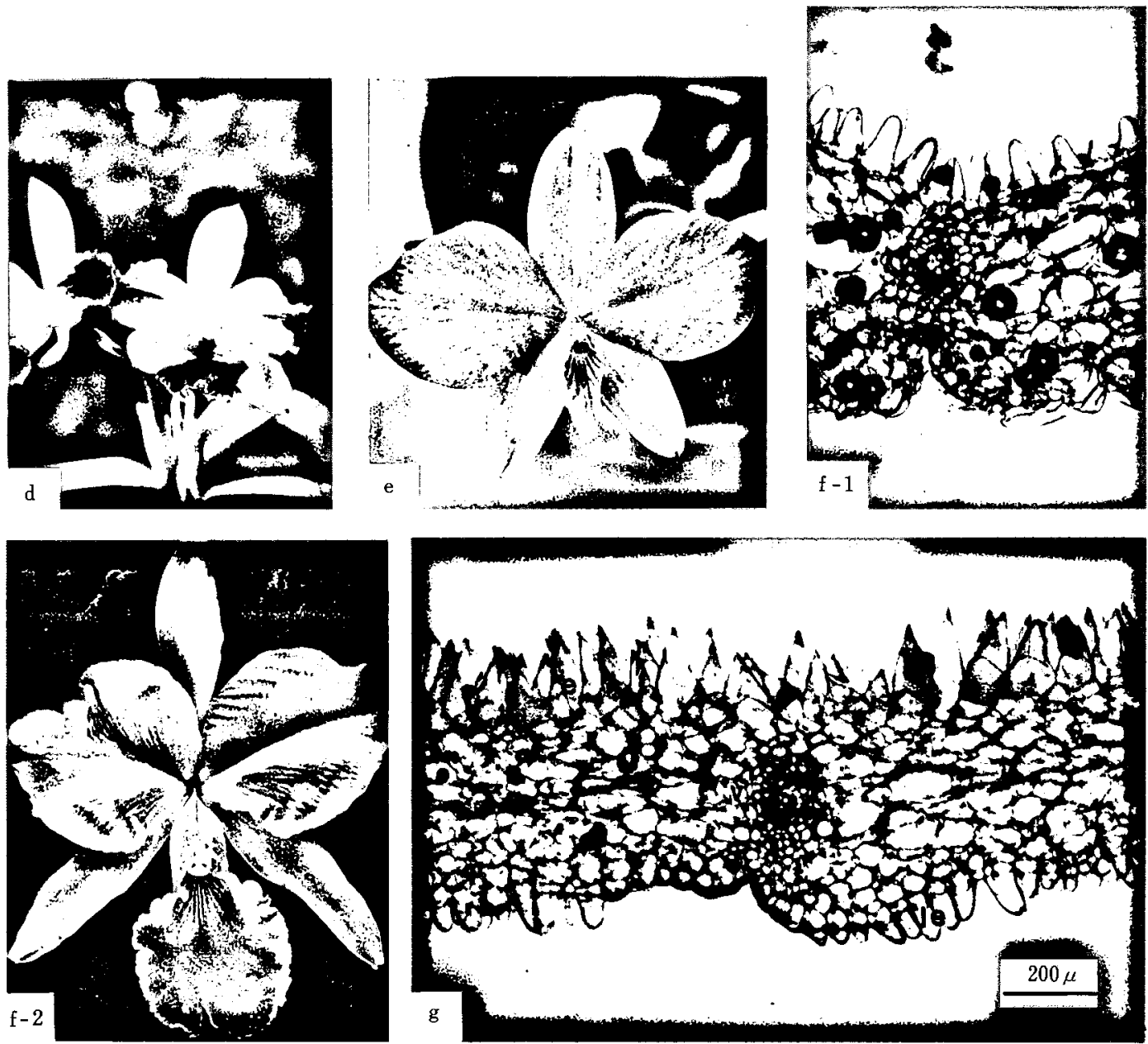

Fig. 1. Flower colors and distribution of pigments in perianth tissues of Laeliinae orchids.

a : Flower color and carotenoids in peeled epidermis of L.cinnabarina petal, b : carotenoids in L.harpophylla petal, $\mathrm{c}:$ anthocyanins in epidermis with carotenoids in L. milleriipetal and its flower color, d : splashed petals of $C$. intermedia var.aquinii, e : Flower color of S. coccinea var rosea, $\mathrm{f}$ : anthocyanins in parencyymatous cells in C.trianae and its flower color, g: anthocyanin distribution in C.mossilae lip. Note; e : epidermis, le : lower epidermis, $\mathrm{p}:$ parenchymatous cell, $\mathrm{v}$ : vascular bundle 
colored lips of most Cattleyas belonged to P 3 as well (Fig. $1 \mathrm{~g}$ ), even when the petals belonged to $\mathrm{P} 2$.

Three species bearing flowers close to blue, C. amethystoglossa var. coerulea, C. intermedia var. coerulea and L.rubescens, were examined. In the lip of the first species, anthocyanins existed in granules in the vacuole of cells and in the second in soluble state in it, whereas in the third species the anthocyanins lay in the colored vacuoles but in granular form in some cells.

Sophronitella is a species close to Sophronitis, and the distribution of anthocyanins was the same (P 1$)$ as that in S.coccinea var. rosea (Fig. $1 \mathrm{e}$ ), which is a variety of $S$ coccinea producing mauve flowers due to the absence of carotenoids. Laelia species such as L.pumila, L. purpurata and L. gouldiana blooming in intensely colored flowers were classified as P 3, although L. pumila and L. purpurata plants with pale pink flowers and L.anceps, morphologically close to $L$. gouldiana, were P 2.

2. Distribution of flower color of species according to Hunter's color chromaticity

In Hunter's color notation, L indicates brightness (value), and $\mathrm{a}$ and $\mathrm{b}$ coordinates give hue $(b / a)$ and chroma $\left(\sqrt{a^{2}+b^{2}}\right)$. The hues and chromas of Laeliinae orchids examined are shown in Fig. 2. It can be useful to divide the diagram into three sections on the basis of hues and the presence or absence of carotenoid and anthocyanin pigments. The same procedure has been used as in a survey of miscellaneous orchids by Yokoi (13). The section in which $\mathrm{b} / \mathrm{a} \geqq .47$ included greenish-yellow to yellow flower species such as C.dowiana, and L. xanthina, the well-known parents of yellow hybrids. $L$. cinnabarina (Fig. 1 a), Epi. cinnabarinum, $E n$. vitellina and $C$.aurantiaca bear similar orange flowers; therefore, their hues were close to each other. This section was characterized by the carotenoid origin of the colors. However, L.tenebrosa, a parent of yellow hybrids, En.aromatica, En.cordigera, $C$. bicolor and Schom. thompsoniana, all of which have brown flowers due to the presence of carotenoids, chlorophylls and anthocyanins,

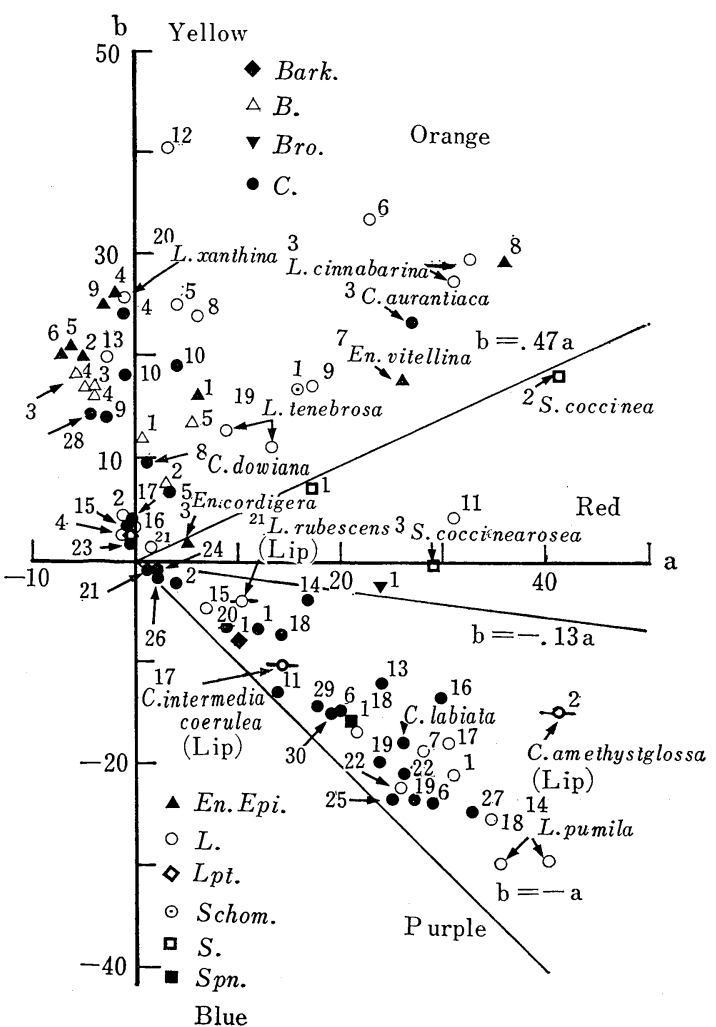

Fig. 2. Distribution of petal colors in Laeliinae orchids on a Hunter's color chromaticity diagram. Numbers are of species shown in Table 1.

were located close to the origin, presenting no hue with low brightness.

The species in the section bounded by $-.13 \leqq \mathrm{~b} / \mathrm{a}<.47$ display red flowers and contained coexisting carotenoids and anthocyanins with one exception (Fig. 1 c). This section corresponded to the $\mathrm{R}$ and $\mathrm{R}^{\prime}$ distribution patterns in the Table 1 . One representative species was $S$.coccinea, which is the most fascinating and the most valued because it bears a true red flower itself and hands down its ability to descendants. S. coccinea var. rosea was located in the red color section in spite of the absence of carotenoids.

Most 'orchid tone' colored petals were located in the range between -.13 and -1.0 and characterized by the presence of anthocyanins only (Fig. $1 \mathrm{f}$ ). In some species varietal plants called 'coerulea' having more purplish flowers than usual are found. The two 'coerulea' varieties of C.amethystoglossa and 


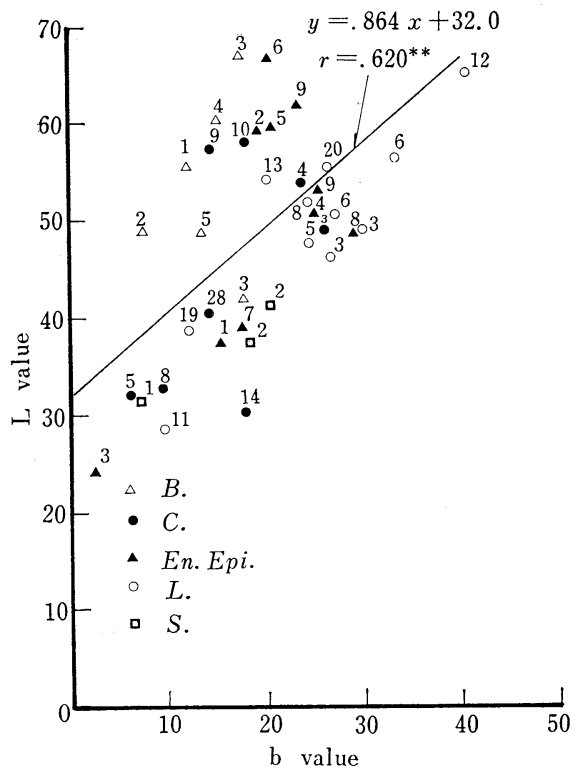

Fig. 3. Relationship between brightness and $b$ values of petals containing carotenoids or both carotenoids and anthocyanins. Numbers are of species shown in Table 1.

C. intermedia had almost the same b/a values for petals which were more than -1.0 like those of C.labiata and L. pumila, and the hues their lips were similar to those of the latter species. However, distinct difference are observable by the naked eye.

High chroma is considered indicative of high carotenoid and anthocyanin contents and it is expected to correlate with brightness. A regression equation relating brightness ( $\mathrm{L}$ values) and $b$ values (yellowness) of petals in species containing carotenoids alone and those containing both carotenoids and anthocyanins was as follows : $y=.864 x+32.0$, $r=.620^{* *}$ (Fig. 3). Brightness is positively related to the amount of carotenoid expressed by the $b$ values. In the species containing only anthocyanins in their petals and lips, regression correlating brightness and chroma were $y=.940 x+68.8, \quad r=-.930 * *$ for petals and $y=-.596 x+51.2, \quad r=-.498^{* *}$ for lips (Fig. 4). Obviously, high levels of anthocyanins decreased brightness. Data on sepals is omitted because of the similarity of their hue to petals.

3. Shape and size of upper epidermal
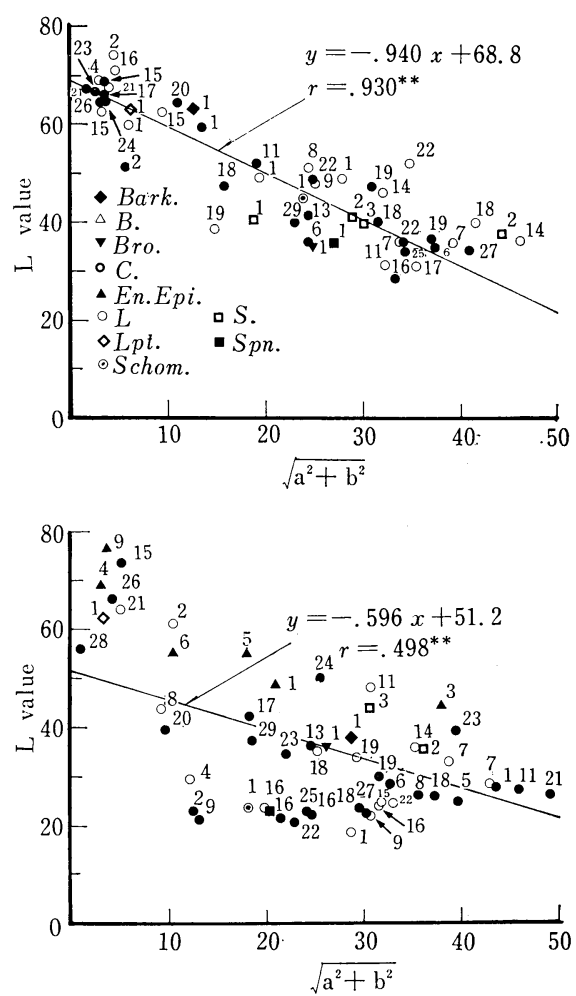

Fig. 4. Relationship between brightness and chromas of petals (above) and of lips (bottom) containing anthocyanins. Numbers are of species shown in Table 1.

cells

Floral organs are referred to as floral leaves. The original shape and size of their epidermal cells might be noticed in cells of leaves which are small and square. Changes in shape from square to deltate suggest the direction of evolution in the genera. In Laeliinae orchids, serial variations in the shape and size of the upper epidermal cells of petals and lips were found. Five typical shapes appeared:C. aurantiaca, with square cells in both petals and lips (a-type); $L$. harpophylla, square cells in petals and deltate ones in lips (h-type); L. flava, deltate cells in both petals and lips (f-type); $L$. purpurata, deltate cells in petals and long deltate or triangular ones in lips (p-type); C.labiata, long deltate cells in both petals and lips (1-type). As shown in Fig. 5, the Cattleya genera showed the most varietal 


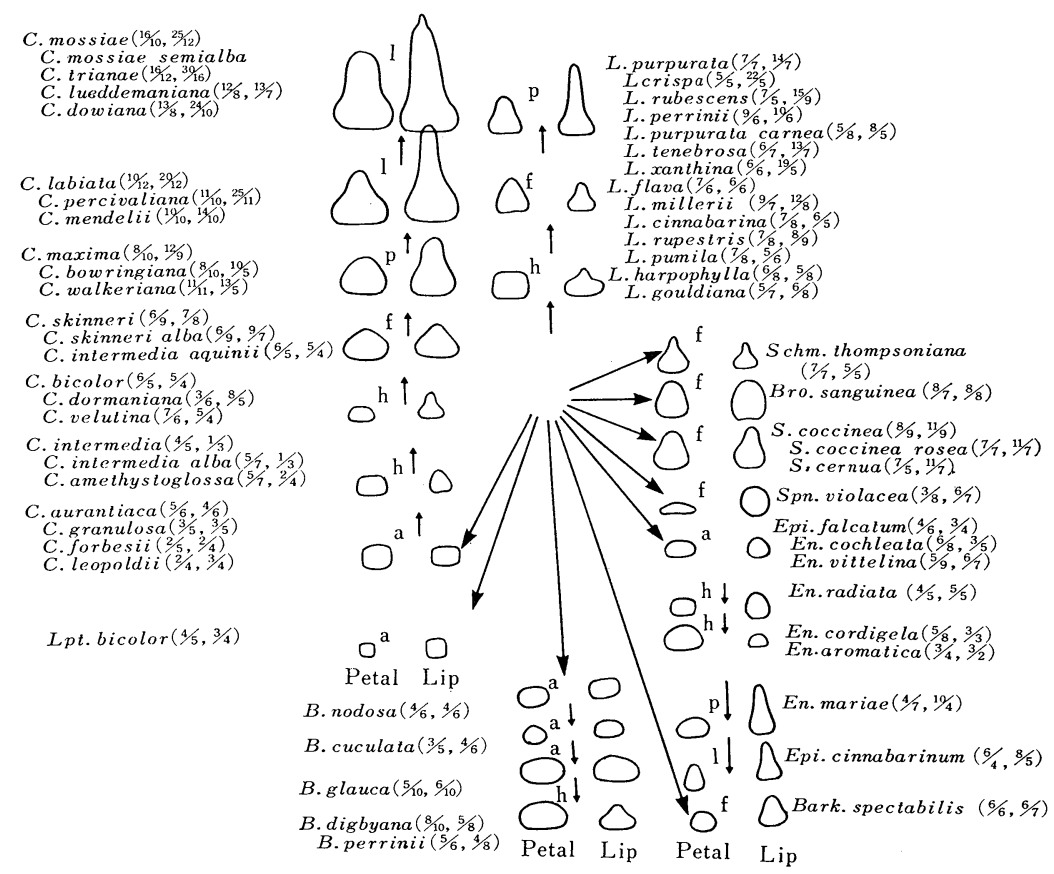

Fig. 5. Changes in size and shape of epidermal cells in perianth of Lealinae orchids.

${ }^{2} 16 / 10$ and $25 / 12$ indicate height and width of cells in petal and lip, respectively $(\times 10 \mu)$ a : C. aurantiaca type, $\mathrm{h}:$ L. harpophylla type, $\mathrm{f}: L$. flava type $\mathrm{p}:$ L. purpurata type, $1:$ C. labiata type.

difference in shapes and sizes of epidermal cells in perianth.

It is noticeable that the greater the size of the epidermal cells and the more deltate their shape, the more showy and larger the flowers were. These species were C.labiata, L. purpurata. En. mariae and B. digbyana, all of which have produced so many excellent progeny by interspecific and intergeneric crossings as to prove their significant parentage.

The shape and size of epidermal cells, especially the ratio of height to width, affect flower texture. C.aurantiaca produces glossy flowers, and the height/width ratio of its epidermal cells, each shaped like a brick, was less than 1.0. On the other hand, unifoliate Cattleyas have heavy substances and velvety appearance, and the ratios were high. In addition, when the ratios were large, the color brightness was generally low. A multiple regression equation expressing the $\mathrm{L}$ $\operatorname{value}(y)$ as a function of chroma $(x 1)$ and the ratio of height to width $(x 2)$ was calculated as follows : $y=-1.268 x 1-1.00 \times 2+$ 82.9. The regression coefficient $\mathrm{R}^{2}$ was $898^{* *}$ and the single regression coefficients for $x 1$ and $x 2$ were $-.782^{* *}$ and $-.582^{* *}$, respectively. This shows that high ratios as well as high chroma correlate with low brightness.

\section{Discussion}

It is said that flower pigments are usually contained in the epidermis(12), and indeed, a microphotograph of a petal section of a Papiyopedilum hybrid shows anthocyanins in the epidermis(4). However, the petals of Cattleya orchids examined first showed no pigment, although the lips contained it as was expected. This finding led to further investigation in other genera and species.

Leaves, especially the lower surface, of 
species such as B.digbyana, C.labiata, L. cinnabarina, Lpt. bicolor and S. coccinea, exhibit the anthocyanin pigmentation. In all of them the pigmentation was observed in the parenchymatous tissue, not in the epidermis (P 2). Thus, considering that perianths are floral leaves, species classified into P 2 could be manifesting the original distribution pattern of anthocyanins. P 3 species might have originated from those of $\mathrm{P} 2$. This was evidenced by the P 3 anthocyanin pigmentation observed in unusual barred patterns and spots on petals in some Cattleya and Encyclia species, and also by some Laelia species which have the $\mathrm{P} 2$ pattern in pale colored petals but P 3 in deep colored ones. Most species examined, furthermore, exhibited P 3 pigmentation in the lips, which are highly modified and thus more advanced organ than other two petals. The same observation was made of Vandeae orchids(7). Therefore, anthocyanin pigmentation of barred patterns in petals and of lips might be related to evolutional direction. At the same time, it has taxonomic significance ; Cattleya is regarded as the genus containing no anthocyanin in the epidermis of the petals, whereas Sophronitis, Sophronitella and Broughtonia have it. These genera could be intermediated by Laelia because Laelia showed both P 2 and P 3 distributions.

The $\mathrm{P} 2$ distribution is also related to the so-called 'orchid tone' or lavender color (Fig. $1 \mathrm{f})$. The distribution in Cattleya species was measured as a narrow hue in the chromaticity diagram, showing no presence of true blue flowers. This might be due to the likely presence of only one anthocyanidin in the flowers ; Robinson and Robinson(8), Lawrence $e t$ al.(6) and Yokoi (13) found the same anthocyanin, cyanidin, in C. labiata, C. skinneri and C.bowringiana, respectively.

Another interesting point concerns the socalled 'sophro' red presented by Sophronitis and its progeny. The flower color of S. coccinea var. rosea (Fig. $1 \mathrm{e}$ ) is so clear and reddish with a velvety appearance as to be clearly distinguishable from 'orchid tone' color and exemplifies the meaning of 'sophro' red. The difference in these colors was observable under the microscope ; the epidermis of the perianth in $S$.coccinea rosea had more reddish vaculoes than that of the latter. This might be thought to be related to the consistent data of Robinson and Robinson (8) that $S$. coccinea species contains pelargonidin and Cattleya species cyanidin in their petals. However, according to Yokoi (13), cyanidin is found in the former species, so that another explanation is needed.

The true red coloration of $S$. coccinea flowers, as indicated in the literary meaning of 'coccinea', was revealed under microsocopic observation to be expressed by virtue of the coexistence of anthocyanins and carotenoids rather than that of anthocyanins and flavones as stated in Die Orchideen(10). This observation corresponds with the result of the chemical anlysis by Yokoi(13), who refers to the coloration as a background effect of carotenoids on the cyanin color expression, and with a phenomenon found in Renanthera orchids(7). This finding can also explain why $S$.coccinea rosea and the yellow plant of L. milleri produce mauve and yellow flowers, respectively; their species lack either carotenoids or anthocyanins. This knowledge can also be used to obtain new hybrids yielding yellow, red and purple flowers, as exemplified by Sophrolaeliocattleya Eastmona, which blooms in yellow flowers that were produced by crossing Slc. Ramona with its sunset toned flowers and Laeliocattleya Goerge Eastman with its white flowers.

Although the epidermis of leaves and yellow petals contain no chloroplasts, some species in different genera such as En. vitellina, Epi. cinnabarinum and L. cinnabarina with orange blooms do contain carotenoids in the epidermis. This difference may be due to the components of carotenoids, that is, decreasing b/a values and changes in color from yellow to orange indicate an increase in hydrocarbon carotenoids such as carotenes in the epidermis.

Serial changes in the shapes and sizes of epidermal cells in each genus, as shown in Fig. 5, might manifest the evolutional direction. These changes also provided the taxonomical significance: all 1-type, an f-type, 
most of h- or a-type Cattleya species belong respectively to Cattleya, Skinneri and $\mathrm{Di}^{-}$ phyllae subgenera as classified by Schlechter (10). Also, p-type Laelias except L.rubescens belong to the same section (Crispa section). On the other hand, that En. mariae is separated from Epidendrum(3) and that B. digbyana is classified as Rhyncolaelia(10) are understandable on the basis of the shape of their cells. The similarity in shape and size of epidermal cells among L. pumila, $L$. milleri, S. coccinea, Bro. sanguinea and Sophronitella suggests that they are closely related. In adition, they contained anthocyanins in their epidermal cells, and three species, L. milleri, S. coccinea and Bro. sanguinea, also contained carotenoids, as mentioned above.

A velvety and substantial texture is one of the desirable flower characteristics. A velvety texture is usually seen in lips, and the data in this study concerning lips show that velvety is defined by high ratios of height to width for epidermal cells and by the presence of anthocyanins. However, these characteristics entail a decrease in petal brightness as shown by the regression equations and by the case of black roses(11). High chromas due to anthocyanin pigmentation also decreased brightness, because the intensively colored vaculoes absorb more light, while the carotenoids increased it, because the granules in the cells easily reflect incident light.

In conclusion, this study has confirmed the well-known facts that desirable characteristics found in C.labiata, L. purpurata, $S$. coccine $a$ and other significant species are concentrated in present hybrids with large purple flowers, whereas the delayed improvement in the breeding of yellow varieties is attributable to scanty stock species, except C. dowiana and L.tenebrosa, which will yield satisfactory progeny. Understanding pigmentation and its inheritance patterns may contribute to the breeding of yellow varieties.

\section{Acknowledgement}

This research was partialy supported by the Grant-In-Aid for Scientific Research(C) No.
56560026 from the Japanese Ministry of Education. The authers are grateful to Nagata Engei Co., Ohgaki Ehgei, Kokusai Nursery Co. and Ohba Orchids Co. for providing valuable orchid flowers.

\section{Literature Cited}

1. ARditTI, J. 1969. Floral anthocyanins in species and hybrids of Broughtonia, Brassavola and Cattleyopsis (Orchidaceae). Amer. J. Bot. $56: 59-68$.

2. ARditTI, J., M. H. FISCH. 1974. Anthocyanins of the Orchidaceae : distribution, heredity, functions, synthesis, and localization. In : J. Arditti (ed.) Orchid biology. 118115. Cornell Univ. Press, Ithaca and London.

3. BeChtel, H., H. P. CRibB and E. LAUnert. 1981. The manual of cultivated orchid species. The MIT Press, Cambridge.

4. JAPANESE ORCHID SOCIETY. 1972. The orchids, culture and breeding. Seibundoshinkosha, Tokyo. (In Japanese)

5. KARASAWA, K. 1973. Present and future of breeding in Cattleyas. Garden Life $12: 38-$ 40. (In Japanese)

6. Lawrence, W. J. C, Jr. J. R. Price, G. M. RobinSON and R. ROBINSON. 1939. The distribution of anthocyanins in flowers, fruits and leaves. Philosophical Trans. Roy. Soc. London ; Ser. B, Biol. Sci. 230 : 149-178.

7. MATSUI, M., T. SUZUKI and M. NAKAMURA. 1984. Distribution of flower pigments in perianth of Vandeae orchids. Res. Bull. Fac. Agri. Gifu University 49 : 361-369.

8. Robinson, G. M., and R. Robinson. 1932. A survey of anthocyanins. II. Biochem. J. 26 : 1647-1664.

9. SANFORD, W. W, 1965 . Paper partition chromatography as an aid to orchid taxonomy. Orchid Rev. $73:$ 178-181.

10. SCHLEChteR, R. 1981. Die Orchideen. Verlag Paul Parey, Berlin.

11. YASUDA, H. 1973. Physiology and biochemistry of flower color. Uchida-Rokkakuho, Tokyo. (In Japanese)

12. YASUDA, H. 1976. Mysteries of flower color. Tokai Univ. Press, Tokyo. (In Japanese)

13. Yokor, M. 1975. Flower colour and pigment distribution in the cultivated species and cultivars of 36 genera of orchids. Tech. Bull. Fac. Hort., Chiba Univ. $14: 20-28$. 
Cattley $a$ およびその近縁属に打ける花被組織の色素分布 I. 原種

松井鋳一郎 - 中村三夫

岐皁大学農学部 501-11 岐阜市柳戸

\begin{abstract}
摘 要
Cattleya とその近縁のラン科 11 属の種の花被組織に おける色素分布拉よび花被表皮細胞の形状を調査し，花 被の表色との関倸を考察した.

1. 供試した 68 種は, 花弁の表皮と栅状拈よび海綿 状組織に括けるカロチノイドとアントシアニンの分布の 違いから 9 群に分類できた. 黄色花は花弁にカロチノイ ドがあるが, Cattleya (C.) dowiana や Laelia (L.) flava などでは柵状・海綿状組織にのみ西り，L. harpophylla や L. cinnabarina などでは表皮細胞にも含まれ ていた.

赤色花には，カロチノイド抢よびアントシアニン両者 ともにあり, Sophronitis coccinea や L. milleri では カロチノイドが表皮拈よび柵状・海綿状組織に，アント シアニンは表皮にのみあった。. L.tenebrosa の褐色の花 弁ではアントシニンは栅状海綿状組織にあった。

赤紫色花はアントシアニンが表皮にのみあるか, 柵状 海綿状組織にあるか，その両者にあるかによって 3 群に 分けられた。Cattleyaはこの花色の 代表的な属である が，多くの種ではアントシアニンは柵状・海綿状組織に あった. C.intermedia var. aquinii や C. leopoldii の花弁着色部分やスポットには表皮細胞にもあった.

Laelia の濃紫赤色花は表皮および栅状・海線状組織と もにアントシアニンを含み, 淡紫赤色のものでは表皮に はなかった。

2. 供試した種は Hunter 表色法によって3群に分け られた、花弁にカロチノイドのみを含む, 黄色ないし橙 色花は色相 (b/a) が 0.47 以上に，カロチノイドとアン トシアニンが共にある赤色花は $0.47 \geqq b / a>-0.13$ に, アントシアニンのみを含むいわゆるカトレア色の紫赤色 花は $-0.13 \geqq \mathrm{~b} / \mathrm{a}>-1.0$ にあった.

カロチノイドを含む花弁では，カロチノイドが多いと 明度が高くなった、アントシアニンのみを含む花弁や唇 弁では，アントシアニンが多いと明度が低くなった。

3. 花弁と唇弁の上面表皮細胞は種によって大きさお よび形に変異がみられた，属を同じくする種ごとにみる 之変異は連続的であり, 小さいものは四角で, 光沢のあ る花にみられ，大きいものはビロード状を示す花にみら れて長三角形であった．表皮細胞の大型化と四角形から 長三角形への変化は進化の方向を示すものと思われ, C. labiata, L. purpurata や Brassavola digbyana な どのように鑑賞価值が高く, 花径の大きな花の表皮細胞 は，それぞれの属内では最大で長三角形であった。
\end{abstract}

